\title{
Quality Improvement of Industrial Products Bungo Mayang to Customer Satisfaction with The Kano Model Approach
}

\author{
Yesmizarti Muchtiar ${ }^{1, *}$, Dessi Mufti ${ }^{1}$, Vil Yosri $^{1}$ \\ ${ }^{1}$ Industrial Engineering Bung Hatta University, Padang, Indonesia
}

\begin{abstract}
The abundance of the home industry appeared in the Batusangkar requires home industry Bungo Mayang should retain the factors that affect the quality of the product so that it can continue to exist and remains sought after by the public. This research aims to identify the attribute customer needs to improve product quality 'kue karambia' Bungo Mayang and classifying the attributes customer needs based on model of Kano. The instrument used was a questionnaire functional and dysfunctional questionnaires grouped into attributes of the Kano must-be, one dimensional, attractive, indifferent, quesionable result, and reverse. From the results of the calculation model Kano note that attributes have the highest grade IE product quality is good $(\mathrm{O}=66)$, the attractive packaging $(\mathrm{O}=61)$, availability of product information $(\mathrm{O}=56)$, and compliance rates $(\mathrm{O}=43)$.
\end{abstract}

\section{Introduction}

Among many traditional cakes produced by Bungo Mayang Industry, a home industry originated from Batusangkar, 'kue karambia' is one of the products which are very less in demand. This is due to the packaging which is only using plain plastic and there is only one original coconut flavor. In order to keep exist in the market; it is of vital importance that product should fits the customer needs. Satisfied customer will be loyal to the produced product.

Customer satisfaction is a determining factor for the success of a business. Hence, it is important for the businessman to keep a continuation on the improvement of the product to win the customer. The businessman has to always understand the needs and the willing of the customer. One of the methods to get to know the level of customer satisfaction is through Kano model. Kano model is a diagram that shares to the customer the satisfaction of the product. It is also a theory to reveal the satisfaction influencing factors of a product or a service, such as taste which is suitable with the customer needs. final printed area will be 130 x $210 \mathrm{~mm}$. Do not add any page numbers.

\footnotetext{
*Corresponding author: yesmizartimuchtiar@bunghatta.ac.id
} 


\section{Literature Review}

\subsection{Customer Satisfaction}

Today marketing concept is one of the management orientations which assume that "customer is the king". Customer is placed in the main position to be served (Adinata, 2013). This marketing concept is implemented to enable the company to provide a more effective and efficient satisfaction to the customer compared to the competitor.

Tjiptono (2002) stated that mostly customer refer to many factors and dimensions in evaluating their satisfaction toward the product, service or certain company.

\subsection{Kano Concept}

KANO model developed by Prof. Noriaki Kano (1984) is a model which aimed to categorized attributes of the product or service based on its ability to satisfy customer needs.

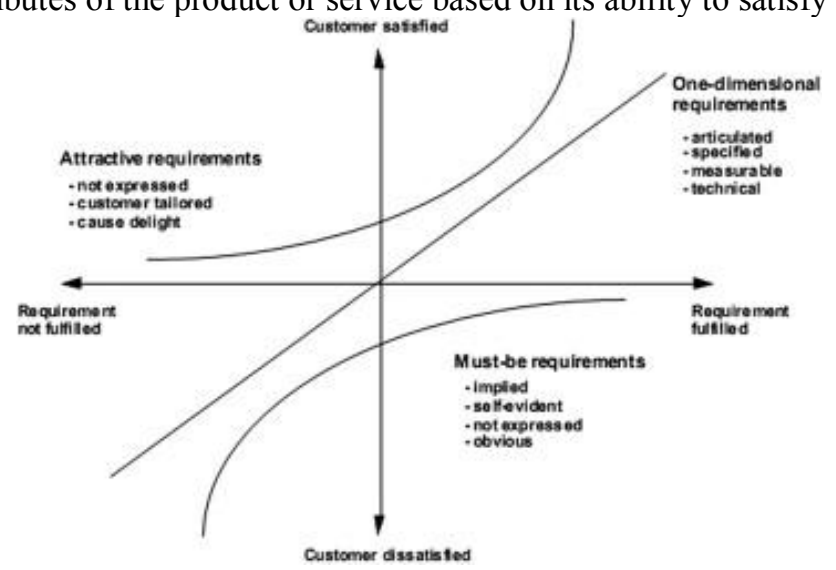

Fig.1. Kano Diagram

Table 1. KANO Method Evaluation Table

\begin{tabular}{|c|c|c|c|c|c|c|}
\hline \multicolumn{2}{|c|}{ Customer Needs } & \multicolumn{5}{|c|}{ Dysfunctional Questions (negative) } \\
\hline \multicolumn{2}{|c|}{$\downarrow$} & 1. Like & 2. Must-be & 3. Neutral & 4. May & 5. Dislike \\
\hline \multirow{5}{*}{$\begin{array}{l}\text { Functional } \\
\text { Question } \\
\text { (Positive) }\end{array}$} & 1. Like & Q & A & A & A & $\mathrm{O}$ \\
\hline & 2. Must-be & $\mathrm{R}$ & I & I & I & $\mathrm{M}$ \\
\hline & 3. Neutral & $\mathrm{R}$ & I & $\mathrm{I}$ & $\mathrm{I}$ & $\mathrm{M}$ \\
\hline & 4. May & $\mathrm{R}$ & I & I & I & $\mathrm{M}$ \\
\hline & 5. Dislike & $\mathrm{R}$ & $\mathrm{R}$ & $\mathrm{R}$ & $\mathrm{R}$ & $\mathrm{Q}$ \\
\hline
\end{tabular}

This table allowing conclusion drawing on whether the needs of customers can be categorized into one of the following:
a. $\mathrm{A}=$ Attractive
b. $M=$ Must-be
c. $\mathrm{O}=$ One-Dimensional
d. $\mathrm{R}=$ Reverse
e. $\mathrm{Q}=$ Questionable
f. $I=$ Indifferent 


\subsection{Kano Stages}

This research was resulted from the interview and filled questionnaire in the form of customer needs characteristic toward quality performed by Bungo Mayang Industry.

\section{Result and Discussion}

\subsection{Kano Model Method}

The determination of Kano category can be obtained from the questionnaire distribution. The product and service concepts, which consist of Core Product, Actual Product, and Extended Product, produce result mapping as can be seen on table 2.

Table 2. Kano Attribute Based on the Product and Service Concepts

\begin{tabular}{|l|l|l|}
\hline No & Attribute & Kano Concept \\
\hline 1 & Attractive packaging & Core Product \\
\hline 2 & The availability of product information & Extended Product \\
\hline 3 & The availability of color variation & Core Product \\
\hline 4 & Product size suitability & Core Product \\
\hline 5 & The availability of product flavor variation & Core Product \\
\hline 6 & Famous brand & Actual Product \\
\hline 7 & The uniqueness of a product & Actual Product \\
\hline 8 & Good quality product & Actual Product \\
\hline 9 & Price suitability & Actual Product \\
\hline 10 & Attractive Logo & Core Product \\
\hline
\end{tabular}

The functional and dysfunctional questionnaires were employed to conduct calculation whichis based on KANO evaluation table. Attribute categorization is implemented to see the influence of each attribute toward the customer satisfaction.

\section{- One Dimensional ( O )}

It is a very important attribute categorization to put into priority by Bungo Mayang Industry. This is due to the level of satisfaction is in linear correlation with the attribute performance. Factors including in this category can be seen on table 3 .

Table 3. One Dimensional Factors

\begin{tabular}{|c|l|c|}
\hline No & \multicolumn{1}{|c|}{ Attribute } & Grade \\
\hline 1 & Attractive packaging & $\mathrm{O}$ \\
\hline 2 & The availability of product information & $\mathrm{O}$ \\
\hline 3 & Good quality product & $\mathrm{O}$ \\
\hline 4 & Price suitability & $\mathrm{O}$ \\
\hline
\end{tabular}

\section{- Indifferent ( I)}

It is not a crucial attribute categorization for the customer. Therefore, its availability will not influence the improvement and decline of the customer satisfaction level. Factors including in this category can be seen on table 4. 
Table 4. Indifferent Factors

\begin{tabular}{|c|l|c|}
\hline No & \multicolumn{1}{|c|}{ Attribute } & Grade \\
\hline 1 & The availability of color variation & I \\
\hline 2 & Product size suitability & I \\
\hline 3 & The availability of product color variation & I \\
\hline 4 & Famous brand & I \\
\hline 5 & The uniqueness of a product & I \\
\hline 6 & Attractive Logo & I \\
\hline
\end{tabular}

\subsection{Kano Method Assessment}

This stage implemented the calculation of better and worse values. Better value indicates the improvement level of customer satisfaction on the availability of A\&O feature. Meanwhile worse indicates the decline of the customer satisfaction on the unavailability of O\&M feature. The following is the formulation to calculate better and worse:

Better $=\frac{A+O}{A+O+M+I}$

Worse $=$

Table 5. Better and Worse Values Recapitulation

\begin{tabular}{|c|c|c|c|c|c|c|}
\hline Variable & A & M & O & I & Better & Worse \\
\hline 1 & 17 & 14 & 61 & 9 & 0,77 & 0,74 \\
\hline 2 & 10 & 18 & 56 & 15 & 0,66 & 0,74 \\
\hline 3 & 26 & 10 & 15 & 45 & 0,42 & 0,26 \\
\hline 4 & 17 & 17 & 26 & 35 & 0,45 & 0,45 \\
\hline 5 & 14 & 12 & 10 & 51 & 0,27 & 0,25 \\
\hline 6 & 20 & 12 & 10 & 52 & 0,31 & 0,23 \\
\hline 7 & 18 & 15 & 7 & 57 & 0,25 & 0,22 \\
\hline 8 & 4 & 15 & 66 & 14 & 0,70 & 0,81 \\
\hline 9 & 8 & 20 & 43 & 25 & 0,53 & 0,60 \\
\hline 10 & 27 & 10 & 24 & 35 & 0,53 & 0,35 \\
\hline
\end{tabular}

Considering the customer expectation toward the product of Bungo Mayang Industry, the attributes that need to keep improved are as follow:

1. Attractive packaging

2. The availability of product information

3. Good quality product

4. Price suitability

\section{Conclusion}

Based on research conducted, it can be concluded that:

1. The calculation result of KANO model reveals respondent answer assessment with KANO diagram, it is known that the biggest interpretation only exist at $\mathrm{O}$ and I categories, as follow:

2. Based on the calculation of better and worse values, it is known that attributes which influence the customer satisfaction improvement level are as follow: 
- $\quad$ Attractive packaging, where customer satisfaction level reaches $77 \%$.

- Good quality product, where customer satisfaction level reaches $70 \%$ only if Bungo Mayang Industry can fulfill the requirement.

- The availability of product information, where customer satisfaction level reaches $66 \%$.

- Price suitability, where customer satisfaction level reaches $53 \%$ only if the requirement can be fulfilled.

\section{References}

1. Nofirza and Indrayani, K. Aplikasi Metode Kano dalam Analisis Indikator Kualitas Pelayanan di Rumah Sakit Arifin Ahmad Pekanbaru. Jurnal Sains, Teknologi, dan Industri. 9(1). 1-8.(2011)

2. Noriaki, Kano. Attractive Quality and Must-be Quality. The Journal of the Japanese Society for Quality Control. (1984)

3. Rangkuti, Fendy. Measuring Customer Satisfaction. Jakarta. PT. Gramedia Pustaka Utama (2000)

4. Tjiptono, Fendi. Prinsip-Prinsip Total Quality Service. Yogyakarta. Andi Offset (1997)

5. Tjiptono, Fendi. Service Quality \& Satisfaction. Yogyakarta. Andi Offset (2008) 